\title{
Oxidative Dehydration of Glycerol to Acrylic Acid over Vanadium-Impregnated Zeolite Beta
}

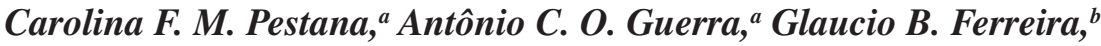 \\ Cássia C. Turci ${ }^{a}$ and Claudio J. A. Mota*,a,c
}

\author{
${ }^{a}$ Instituto de Química, Universidade Federal do Rio de Janeiro, \\ Av. Athos da Silveira Ramos 149, CT Bloco A, 21949-900 Rio de Janeiro-RJ, Brazil \\ ${ }^{b}$ Instituto de Química, Universidade Federal Fluminense, 24020-150 Niterói-RJ, Brazil \\ 'INCT Energia e Ambiente, Universidade Federal do Rio de Janeiro, \\ 21941-909 Rio de Janeiro-RJ, Brazil
}

\begin{abstract}
A desidratação oxidativa do glicerol a ácido acrílico foi estudada com o uso de zeólita Beta impregnada com vanádio. Os catalisadores foram preparados por impregnação úmida do metavanadato de amônio sobre a zeólita Beta na forma amoniacal, seguida de calcinação em ar a 823 K. A impregnação reduziu a área superficial específica, mas não afetou significativamente a acidez (Brønsted e Lewis) da zeólita. A avaliação dos catalisadores foi realizada num reator de leito fixo usando ar como gás de arraste e injetando o glicerol por meio de uma bomba seringa. Acroleína foi o principal produto formado, tendo também sido observados acetaldeído e hidróxi-acetona (acetol). O ácido acrílico foi formado em aproximadamente $25 \%$ de seletividade a $548 \mathrm{~K}$ sobre as zeólitas impregnadas. O resultado pode ser explicado por análises de XPS (espectroscopia fotoeletrônica de raios X), que mostraram uma boa dispersão de vanádio nos poros da zeólita.

The oxidative dehydration of glycerol to acrylic acid was studied over vanadium-impregnated zeolite Beta. Catalysts were prepared by wet impregnation of ammonium metavanadate over ammonium-exchanged zeolite Beta, followed by air calcination at $823 \mathrm{~K}$. Impregnation reduced the specific surface area, but did not significantly affected the acidity (Brønsted and Lewis) of the zeolites. The catalytic evaluation was carried out in a fixed bed flow reactor using air as the carrier and injecting glycerol by means of a syringe pump. Acrolein was the main product, with acetaldehyde and hydroxy-acetone (acetol) being also formed. Acrylic acid was formed with approximately $25 \%$ selectivity at $548 \mathrm{~K}$ over the impregnated zeolites. The result can be explained by XPS (X-ray photoelectron spectroscopy) measurements, which indicated a good dispersion of the vanadium inside the pores.
\end{abstract}

Keywords: glycerol, acrylic acid, zeolite, dehydration, oxidation

\section{Introduction}

Glycerol is usually found in combination with fatty acids of natural occurrence forming the triglycerides. Today, the major source of glycerol is the transesterification of oils and fats to produce biodiesel. ${ }^{1}$ In this reaction, a molecule of triglyceride reacts with three molecules of methanol, under base catalysis conditions, to afford three molecules of fatty acid methyl esters (the biodiesel) and a molecule of glycerol (Scheme 1). In recent years, the growing concern about global warming has motivated the

*e-mail: cmota@iq.ufrj.br use of biofuels. Biodiesel, together with bioethanol, is one of the most important biofuels used nowadays.

For each $90 \mathrm{~m}^{3}$ of biodiesel produced by transesterification, about $10 \mathrm{~m}^{3}$ of glycerol are obtained. The worldwide glycerol production will reached ${ }^{2}$ approximately 1.2 million tons in 2012 and most of this production will come from the biodiesel industry. In Brazil, for instance, there is a mandatory blend of $5 \%$ of biodiesel in the petrodiesel, which represents an annual glycerol production of approximately 300,000 tons. The traditional markets for glycerol are cosmetics, soaps, pharmaceuticals and personal care products. However, with the increasing production and availability, glycerol will be an interesting feedstock for the 
<smiles>[R]C(=O)OCC(COC([R])=O)OC([R])=O</smiles>

Scheme 1. Transesterification of triglycerides to produce biodiesel.

chemical industry, because of price concerns and for being a renewable material.

Glycerol obtained from biodiesel production can be used in the synthesis of many chemicals, in what some people call glycerochemistry. ${ }^{3-5}$ Replacing oil as feedstock in the chemical industry is one of the main challenges for the coming years. Hydrogenolysis of glycerol over metal catalysts can produce 1,2- and 1,3-propanediol, ${ }^{6-9}$ used in the production of polymers and as anti-freezing agents. Carbonation of glycerol produces glycerol carbonate ${ }^{10,11}$, used as solvent. Acid-catalyzed reaction of glycerol with isobutene ${ }^{12,13}$ affords a mixture of tert-butyl glyceryl ethers, which are potential fuel additives. Etherification can also be accomplished by the reaction of glycerol with alcohols under acid catalysis conditions. ${ }^{14,15}$ Glycerol ketals and acetals are formed in the acid-catalyzed reactions with ketones and aldehydes, respectively. ${ }^{16,17}$ Solketal, the product formed in the reaction of glycerol with acetone, is a potential additive for gasoline,${ }^{18}$ whereas the acetals formed in the reaction of glycerol with butanal improves the cold flow properties of biodiesel. ${ }^{19}$ Metal-supported catalysts are usually employed in the glycerol oxidation, producing many compounds, such as glyceric, mesoxalic and hydropyruvic acid..$^{20,21}$

Dehydration of glycerol is known to occur under acid-catalyzed conditions, following two pathways: dehydration of the primary hydroxy group affords hydroxy-acetone or acetol as the main product, whereas dehydration of the secondary hydroxy group produces 3-hydroxypropanal, which can be subsequently dehydrated to acrolein (Scheme 2), an important chemical used in the industrial production of acrylic acid and amino-acids such as methionine. The economic importance of glycerol dehydration to acrolein was recently addressed in a short review, ${ }^{22}$ which also discussed the use of different catalytic systems.

Chai et $a l .{ }^{23}$ have studied the glycerol dehydration over several solid acid catalysts. The main finding was that materials with moderate acid strength, such as niobic acid and zeolite HZSM-5, presented the best results, with selectivity to acrolein in the order of 60 to $70 \%$. Highly acidic materials, such as sulfated zirconia, presented many secondary reactions, leading to a decrease in the acrolein selectivity. Solids of low acid strength, such as cerium and lanthanum oxides, showed low catalytic activity.

Supported heteropolyacids can also be used in the glycerol dehydration, ${ }^{24,25}$ but depending on the nature of the support, they can be destroyed under reaction conditions due to the formation of water as by-product. It was shown ${ }^{26}$ that phosphorus-molybdenum heteropolyacids are preferred over phosphorus-tungsten ones in the glycerol dehydration to acrolein. At $548 \mathrm{~K}, \mathrm{H}_{3} \mathrm{PMo}_{12} \mathrm{O}_{40}$ supported

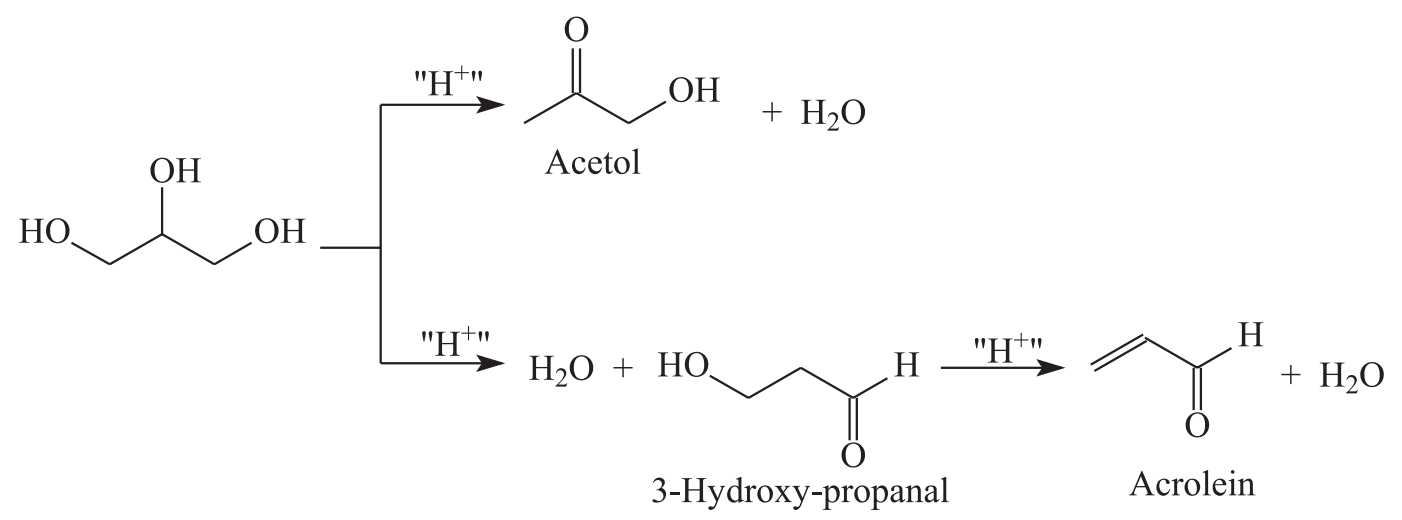

Scheme 2. Glycerol dehydration pathways leading to acrolein or acetol. 
on mesoporous silica showed a selectivity of $86 \%$ to acrolein for a glycerol conversion of $98 \%$.

Glycerol dehydration has also been studied over alumina and activated carbon impregnated with phosphoric acid. ${ }^{27} \mathrm{Up}$ to $84 \%$ of selectivity to acrolein was observed, with reduced catalyst deactivation. Recently, sulfonated SBA-15 materials has been used as catalyst in glycerol dehydration to acrolein with $80 \%$ selectivity to acrolein. ${ }^{28}$

Zeolites are one of the most versatile solid acid catalysts used in industry. A recent study ${ }^{29}$ compared different zeolitic structures toward glycerol dehydration to acrolein. $\mathrm{H}$-ferrierite showed the highest selectivity among the zeolite tested. The external surface area influenced the glycerol conversion, as the zeolite pores become blocked by carbonaceous materials at the initial stages of the reaction. Indeed, catalyst deactivation is a major problem associated with acid-catalyzed glycerol dehydration. Mixed niobium-zirconium oxides are among the most resistant catalysts for glycerol dehydration, ${ }^{30,31}$ showing $82 \%$ conversion even after $177 \mathrm{~h}$ on stream.

A less studied approach is the glycerol oxidative dehydration, which is carried out over bifunctional catalysts in the presence of air or oxygen. The idea is to perform two consecutive reactions: glycerol dehydration to acrolein and its subsequent oxidation to acrylic acid. Another advantage of the oxidative dehydration is the possibility of continuously regenerating the catalysts via coke burning.

Acrylic acid has many uses, going from the synthesis of superabsorbent polymers used in diapers, to printer inks and adhesives. It may be produced through the oxidation of acrolein on mixed oxide systems, such as Mo-V, Mo-Co, $\mathrm{V}-\mathrm{Sb}^{32}$ The industrial catalyst has a complex structure formed by V-Mo-W oxides. ${ }^{33}$

Deleplanque et al.$^{34}$ studied the glycerol oxydehydration to acrylic acid over mixed oxide catalysts in the presence of oxygen. They were able to find up to $28 \%$ selectivity to acrylic acid over Mo-V-Te-Nb mixed oxides. The major organic by-products were acrolein, acetaldehyde and acetic acid. This later compound was probably formed by the oxidation of acetaldehyde. A series of vanadium pyrophosphate oxides was also tested in the oxidative dehydration of glycerol. ${ }^{35}$ Although the conversion could reach $100 \%$ in some cases, the selectivity to acrylic acid was not more than $1 \%$, with acrolein, acetaldehyde and acetol as main products. Ulgen and Hoelderich ${ }^{36,37}$ have studied the glycerol oxydehydration over supported tungsten oxide. Although the observed conversions were high, the selectivity to acrylic acid was below $5 \%$, with acrolein being the main product. Soriano et al..$^{38}$ studied the oxidehydration of glycerol over tungsten and vanadium mixed oxides, obtaining about $20 \%$ selectivity to acrylic acid. They reported that during the course of the reaction, under the oxygen-rich feed, $\mathrm{V}^{4+}$ underwent a slow oxidation to $\mathrm{V}^{5+}$ causing a decrease in the selectivity to acrylic acid with time on stream.

These results prompted us to report our preliminary results on glycerol oxidative dehydration to acrylic acid over vanadium-impregnated zeolite catalysts (Scheme 3). Vanadium-containing zeolites have attracted attention for its acid and redox features, and also for their interesting properties as a catalyst. ${ }^{39}$

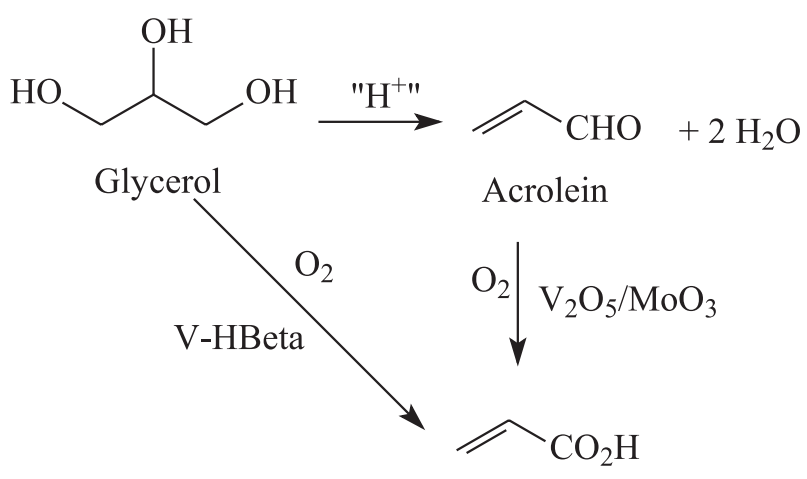

Acrylic acid

Scheme 3. Pathways for glycerol transformation in acrylic acid: two-step process, involving dehydration to acrolein and subsequent oxidation to acrylic acid, and the one-step process using vanadium-impregnated zeolite Beta.

\section{Experimental}

The catalysts were prepared from a commercial ammonium-exchanged zeolite Beta (Zeolyst). Vanadium impregnation was carried out by wet impregnation. An aqueous solution of ammonium metavanadate was stirred at room temperature with ammonium-exchanged zeolite Beta for $24 \mathrm{~h}$. At the end, the water was evaporated to obtain the impregnated zeolite, which was then calcined in air at $823 \mathrm{~K}$ for $2 \mathrm{~h}$. A physical mixture of the acidic Beta zeolite, obtained by calcination of the ammonium-exchanged zeolite at $823 \mathrm{~K}$, and vanadium pentoxide was also prepared for comparison purpose. The impregnated zeolites were named $5 \% \mathrm{~V} / \mathrm{BEA}_{\mathrm{w}}$ and $10 \% \mathrm{~V} / \mathrm{BEA}_{\mathrm{w}}$, in which the number accounts for the nominal amount of vanadium in the catalyst. The parent acidic zeolite was named HBEA, whereas the physical mixture was named $5 \% \mathrm{~V} / \mathrm{BEA}_{\mathrm{m}}$.

The chemical composition of the catalysts was determined by X-ray fluorescence, whereas the specific surface area was measured by nitrogen adsorption using the BET equation. To have some insight of the dispersion of the vanadium into the zeolite channels, a preliminary analysis was carried out using the soft X-ray spectroscopy (SXS) 
beam line at National Laboratory of Synchrotron Light (LNLS), in Campinas, Brazil. The X-ray photoelectron spectra (XPS) of the calcined zeolites were measured at the $\mathrm{Si}$ 1s, Al 1s, O 1s and V 2p edges. Before the measurements, all zeolites samples were kept under heating for 8 to $10 \mathrm{~h}$ at $423 \mathrm{~K}$ to help the water desorption. The samples were introduced in the main chamber as a solid using a carbon sticky tape. The work pressure was maintained at $4 \times 10^{-8}$ mbar. During the measurements all parameters such as pressure, incident beam current and acquisition time were, either, held constant, or variations in their values were measured and taken into account. Thus, the raw data was systematically normalized to beam current, pressure and acquisition time. Finally, the background was removed by subtracting a smooth curve determined from a curve fit of a linear function to the structure below the onset of core ionization.

The catalytic tests were carried out in a continuous flow unit with fixed bed reactor. Approximately $100 \mathrm{mg}$ of the catalysts were pre-treated under flowing nitrogen gas $\left(40.0 \mathrm{~mL} \mathrm{~min}^{-1}\right)$ at $673 \mathrm{~K}$ for $0.5 \mathrm{~h}$. After the pre-treatment, the temperature was decreased to the desired value (523 or $548 \mathrm{~K}$ ) and nitrogen was replaced by air, at the same volumetric flow. Pure glycerol was introduced $\left(0.12 \mathrm{~mL} \mathrm{~h}^{-1}\right)$ in the system by means of a syringe pump. The reactor effluent was analyzed on-line by gas chromatography with flame ionization detector, using a column $(30 \mathrm{~m}, 0.25 \mathrm{~mm}$ and $0.25 \mu \mathrm{m}$ ) of $50 \%$ cyanopropylmethylsiloxane and $50 \%$ phenylmethylpolysiloxane as stationary phase.

\section{Results and Discussion}

The chemical and textural analyses of the catalysts are shown in Table 1. The vanadium impregnation did not significantly change the $\mathrm{Si} / \mathrm{Al}$ ratio of the zeolites, but led to a decrease in the specific surface area. However, the acidity was not significantly affected as shown in the infrared spectra of adsorbed pyridine (Figure 1). Both, the parent HBEA and the vanadium-impregnated zeolite have almost the same acidity in terms of Brønsted and Lewis sites, indicating that impregnation did not affect them. The amount of vanadium in the impregnated zeolites was close to the nominal content, implying that there was practically no loss of vanadium during impregnation and calcination.

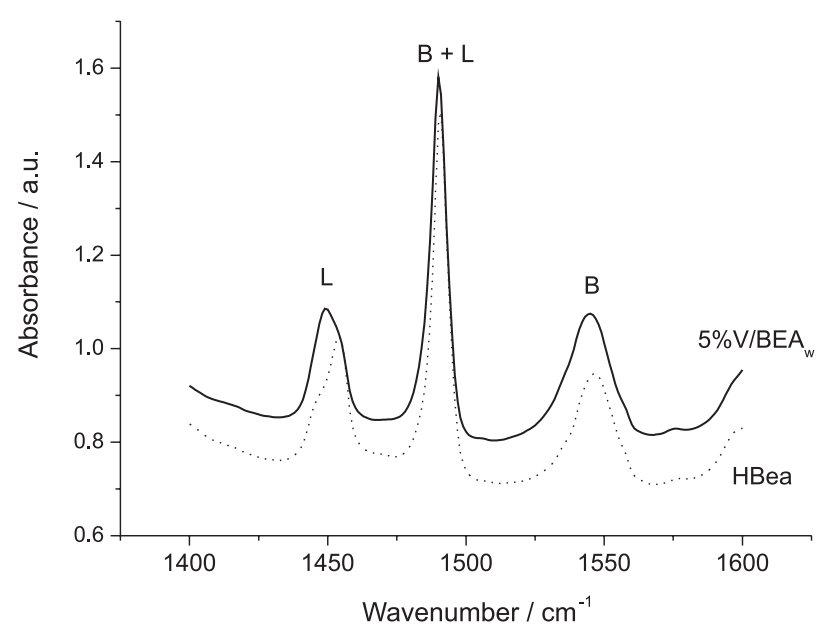

Figure 1. Infrared spectra of pyridine adsorbed on $5 \% \mathrm{~V} / \mathrm{BEA}_{\mathrm{w}}$ and the parent HBEA zeolites. The letters B and $\mathrm{L}$ denote the bands associated with Brønsted and Lewis acidity, respectively.

A control experiment with the zeolite HBEA in flowing nitrogen showed that acrolein and acetol were the main products formed, according to previously published works. ${ }^{23-31}$ Figure 2 shows the conversion and selectivity of the catalysts in the oxidative dehydration of glycerol in the presence of air, at $548 \mathrm{~K}$. Acrolein was still the main observed organic product, but acrylic and acetic acid could also be identified, as well as acetaldehyde, which may be produced from the catalytic cracking of 3-hydroxy-propanal, formed as intermediate (Scheme 2). There was a significant amount of unidentified products, most of them with higher retention times than glycerol, indicative of high boiling point. These products may be associated with the direct oxidation of glycerol to carboxylic acids and hydroxy-aldehydes, because they were not formed when nitrogen was used as carrier gas. The heavier products were especially formed over the zeolite with higher vanadium content and on the physical mixture of the acidic zeolite and $\mathrm{V}_{2} \mathrm{O}_{5}$.

At $523 \mathrm{~K}$, the picture is not significantly different. Glycerol conversion is lower, as well as the selectivity

Table 1. Characterization of the catalysts

\begin{tabular}{|c|c|c|c|c|c|}
\hline \multirow{2}{*}{ Zeolites } & \multicolumn{4}{|c|}{ Chemical composition / wt.\% } & \multirow{2}{*}{ BET area $/\left(\mathrm{m}^{2} \mathrm{~g}^{-1}\right)$} \\
\hline & $\mathrm{Al}_{2} \mathrm{O}_{3}$ & $\mathrm{SiO}_{2}$ & $\mathrm{Si} / \mathrm{Al}$ & $\mathrm{V}$ & \\
\hline $5 \% \mathrm{~V} / \mathrm{BEA}_{\mathrm{w}}{ }^{\mathrm{a}}$ & 3.0 & 88.3 & 24.5 & 5.0 & 310 \\
\hline $10 \% \mathrm{~V} / \mathrm{BEA}_{\mathrm{w}}{ }^{\mathrm{a}}$ & 2.9 & 78.5 & 22.0 & 10.4 & 268 \\
\hline $5 \% \mathrm{~V} / \mathrm{BEA}_{\mathrm{m}}^{\mathrm{b}}$ & 2.9 & 86.2 & 26.0 & 6.1 & 359 \\
\hline HBEA $^{\mathrm{c}}$ & 3.1 & 86.8 & 24.0 & - & 430 \\
\hline
\end{tabular}

${ }^{a}$ Wet impregnation with $\mathrm{NH}_{4} \mathrm{VO}_{3}$; ${ }^{\text {b }}$ physical mixture of HBEA and $\mathrm{V}_{2} \mathrm{O}_{5}$; ${ }^{c}$ acidic zeolite Beta. 


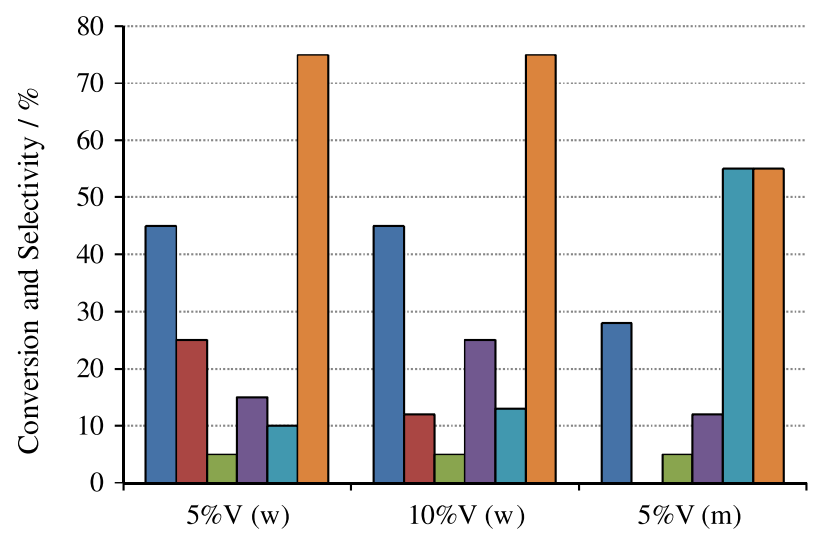

Figure 2. Conversion and selectivity of glycerol oxydehydration over $\mathrm{V}$-impregnated zeolite Beta ( $\mathrm{w}$ stands for wet impregnation and $\mathrm{m}$ stands for physical mixture) at $548 \mathrm{~K}$. ( $\square$ ) Conversion; (๘) acrolein; (๘) acrylic acid; ( $\square$ ) acetaldehyde; ( $\square$ ) acetic acid; ( $\square$ ) others (including acetol and high-boiling point products).

to acrylic acid over the impregnated zeolites. At this temperature, acrolein is still the major organic product, but acetol is significantly formed and contributes to the increase of the selectivity to other products, as shown in Figure 3. High boiling point compounds also appeared at $523 \mathrm{~K}$ and the physical mixture of $\mathrm{V}_{2} \mathrm{O}_{5}$ and HBEA did not produce acrylic acid at this temperature either.

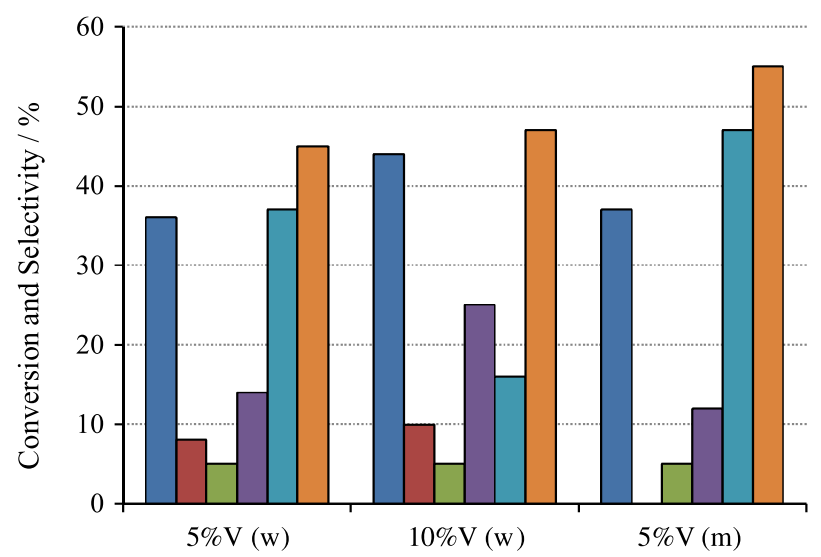

Figure 3. Conversion and selectivity of glycerol oxydehydration over V-impregnated zeolite Beta ( $\mathrm{w}$ stands for wet impregnation and $\mathrm{m}$ stands for physical mixture) at $523 \mathrm{~K}$. ( $\square$ ) Conversion; (๘) acrolein; (๘) acrylic acid; ( $\square$ ) acetaldehyde; ( $\square$ ) acetic acid; ( $\square$ ) others (including acetol and high-boiling point products).

In an attempt to understand the selectivity of the vanadium-impregnated zeolite to acrylic and acetic acids, it was carried out an XPS analysis of the catalysts. This technique provides a semi-quantitative analysis of the outer surface of the zeolites. Table 2 shows the results, which indicated that the vanadium was well dispersed inside the pores of the impregnated zeolites. The external $\mathrm{Si} / \mathrm{Al}$ ratio was slightly higher than the bulk $\mathrm{Si} / \mathrm{Al}$, measured by X-ray fluorescence, in all samples, indicating a silicon-enrichment of the outer surface. The HBEA zeolite showed, as expect, no vanadium peak in the XPS spectrum. The $\mathrm{Si} / \mathrm{V}$ ratio on the vanadium-impregnated zeolites and the physical mixture was significantly higher than the bulk ratio measured by chemical analysis. The $5 \% \mathrm{~V} / \mathrm{BEA}_{\mathrm{w}}$ sample showed the highest $\mathrm{Si} / \mathrm{V}$ ratio, indicating a great dispersion of vanadium inside the pores. The physical mixture of HBEA and $\mathrm{V}_{2} \mathrm{O}_{5}$ also showed an external $\mathrm{Si} / \mathrm{V}$ ratio higher than the bulk ratio, although much lower than the impregnated zeolites. This indicates that some vanadium migration into the pores may occur even with the physical mixture of the components followed by calcination at $823 \mathrm{~K}$. The great vanadium dispersion into the pores in the impregnated zeolites may explain the catalytic results, because the reaction may occur in sequence. Firstly, the glycerol molecule has to be dehydrated over the acid sites to form acrolein. Secondly, the metal function must oxidize the acrolein to acrylic acid. If a great amount of vanadium is deposited on the pore mouth, at the outer zeolite surface, oxidation of glycerol may occur prior to dehydration, leading to different products. This picture may be occurring in the physical mixture, favouring the formation of glycerol oxidation products, such as the heavier products, with greater retention times than glycerol itself. These products are probably formed by glycerol oxidation at the outer surface, and may contain glyceric, mesoxalic and hydropyruvic acid, among other.

Table 2. XPS characterization of the zeolites

\begin{tabular}{lccc}
\hline Zeolites & $\begin{array}{c}\text { Si/Al ratio } \\
\text { (XPS) }\end{array}$ & $\begin{array}{c}\text { Si/V ratio } \\
\text { (XPS) }\end{array}$ & $\begin{array}{c}\text { Si/V ratio } \\
\text { (chemical) }\end{array}$ \\
\hline $5 \% \mathrm{~V} / B E A_{\mathrm{w}}$ & 30 & 97 & 15 \\
$10 \%{\mathrm{~V} / \mathrm{BEA}_{\mathrm{w}}}$ & 28 & 74 & 6.7 \\
$5 \% \mathrm{C} / \mathrm{BEA}_{\mathrm{m}}$ & 32 & 30 & 12 \\
HBEA & 37 & - & - \\
\hline
\end{tabular}

\section{Conclusions}

The glycerol oxidative dehydration to acrylic acid can be achieved with the use of vanadium-impregnated zeolite Beta. Although acrolein is the major organic product, acrylic acid can be formed up to $20 \%$ selectivity.

The results can be explained in terms of the vanadium dispersion inside the pore channels of the impregnated zeolite, as shown by XPS analysis. Compared to a physical mixture of the acidic zeolite and vanadium pentoxide, which was not selective to acrylic acid, the impregnated zeolites showed a lower $\mathrm{Si} / \mathrm{V}$ ratio. This data is consistent with the presence of lower vanadium contents in the outer surface, indicating that a good dispersion within the pore 
system could be achieved with the vanadium impregnation technique used.

\section{Acknowledgements}

Authors thank Conselho Nacional de Desenvolvimento Científico e Tecnológico (CNPq) and Fundação de Amparo à Pesquisa do Estado do Rio de Janeiro (FAPERJ) for financial suport. They also acknowledge Laboratório Nacional de Luz Síncrotron (LNLS) for the XPS characterization of the zeolites.

\section{References}

1. Pinto, A. C.; Guarieiro, L. N.; Resende, M. J. C.; Ribeiro, N. M.; Torres, E. A.; Lopes, W. A.; Pereira, P. A P.; Andrade, J. B.; J. Braz. Chem. Soc. 2005, 16, 1313.

2. Zhou, C. H.; Beltramini, J. N.; Fan, Y. X.; Lu, G. Q.; Chem. Soc. Rev. 2008, 37, 527.

3. Behr, A.; Eilting, J.; Irawadi, K.; Leschinski, J.; Lindner, F.; Green Chem. 2008, 10, 13.

4. Pagliaro, M.; Ciriminna, R.; Kimura, H.; Rossi, M.; Pina, C. D.; Angew. Chem., Int. Ed. 2007, 46, 4434.

5. Mota, C. J. A.; da Silva, C. X. A.; Gonçalves,V. L. C.; Quím. Nova 2009, 32, 639.

6. Dasari, M. A.; Kiatsimkul, P. P.; Sutterlin, W. R.; Suppes, G. J.; Appl. Catal., A 2005, 281, 225.

7. Kusunoki, Y.; Miyazawa, T.; Kunimori, K.; Tomishige, K.; Catal. Commun. 2005, 6, 645.

8. Miyazawa, T.; Kusunoki, Y.; Kunimori, K.; Tomishige, K.; J. Catal. 2006, 240, 213.

9. Furikado, I.; Miyazawa, T.; Koso, S.; Shimao, A.; Kunimori, K.; Tomishige, K.; Green Chem 2007, 9, 582.

10. Aresta, M.; Dibenedetto, A.; Patore, C.; Catal. Today 2006, 115,88 .

11. Aresta, M.; Dibenedetto, A.; Nocito, F.; Patore, C.; J. Mol. Catal. A: Chem. 2006, 257, 149.

12. Karinen, R. S.; Krause, A. O. I.; Appl. Catal., A 2003, 306, 128.

13. Klepacova, K.; Mravec, D.; Bajus, M.; Appl. Catal., A 2005, 294, 141

14. Gu, Y.; Azzouzi, A.; Pouilloux, Y.; Jerome, F.; Barrault, J.; Green Chem. 2008, 10, 164.

15. da Silva, C. R. B.; Gonçalves, V. L. C.; Lachter, E. R.; Mota, C. J. A.; J. Braz. Chem. Soc. 2009, 20, 201.

16. Deutsch, J.; Martin, A.; Lieske, H.; J. Catal. 2007, 245, 428.

17. da Silva, C. X. A.; Gonçalves, V. L. C.; Mota, C. J. A.; Green Chem. 2009, 11, 38.
18. Mota, C. J. A.; da Silva, C. X. A.; Rosenbach Jr., N.; Costa, J.; da Silva, F.; Energy Fuels 2010, 24, 2733.

19. Silva, P. H. R.; Gonçalves, V. L. C.; Mota, C. J. A.; Bioresour. Technol. 2010, 101, 6225.

20. Garcia, R.; Besson, M.; Gallezot, P.; Appl. Catal., A 1995, 127, 165.

21. Bianchi, C. L.; Canton, P.; Dimitratos, N.; Porta, F.; Prati, L.; Catal. Today 2005, 102-103, 203.

22. Katryniok, B.; Paul, S.; Bellière-Baca, V.; Rey, P.; Dumeignil, F.; Green Chem. 2010, 12, 2079.

23. Chai, S. H.; Hang, H. P.; Liang, Y.; Xu, B. Q.; Green Chem. 2007, 9, 1130.

24. Chai, S. H.; Hang, H. P.; Liang, Y.; Xu, B. Q.; Green Chem. 2008, 10, 1087.

25. Chai, S. H.; Hang, H. P.; Liang, Y.; Xu, B. Q.; Appl. Catal., A 2009, 353, 213.

26. Atia, H.; Armbruster, U.; Martin, A.; J. Catal. 2008, 258, 71.

27. Yan, W.; Suppes, G. J.; Ind. Eng. Chem. Res. 2009, 48, 3279.

28. Lourenço, J. P.; Macedo, M. I.; Fernandes, A.; Catal. Commun. 2012, 19, 105.

29. Kim, Y. T.; Jung, K. D.; Park, E. D.; Appl. Catal., A 2011, 393, 275.

30. Lauriol-Garbay, P.; Millet, J. M. M.; Loridant, S.; Bellière-Baca, V.; Rey, P.; J. Catal. 2011, 280, 68.

31. Lauriol-Garbey, P.; Postole, G.; Loridant, S.; Auroux, A.; Belliere-Baca, V.; Millet, J. M.; Appl. Catal., B 2011, 106, 94.

32. Andrushkevich, T. V.; Catal. Rev. Sci. Eng. 1993, 53, 213.

33. Kampe, P.; Giebelder, L.; Smuelis, D.; Kunert, J.; Drochner, A.; Haass, F.; Adams, A. H.; Ott, J.; Endres, S.; Shimanke, G.; Buhrmester, T.; Martin, M.; Fuess, H.; Vogel, H.; Phys. Chem. Chem. Phys. 2007, 9, 3577.

34. Deplanque, J.; Dubois, J. L.; Devraux, J. F.; Ueda, W.; Catal. Today 2010, 157, 351.

35. Wang, F.; Dubois, J. L.; Ueda,W.; Appl. Catal., A. 2010, 376, 25.

36. Ulgen, A.; Hoelderich, W.; Catal. Lett. 2009, 131, 122.

37. Ulgen, A.; Hoelderich, W.; Appl. Catal., A 2011, 400, 34.

38. Soriano, M. D.; Concepcion, P.; Nieto, J. M. L.; Cavani, F.; Guidetti, S.; Trevisanut, C.; Green Chem. 2011, 13, 2954.

39. Teixeira-Neto, A. A.; Pastore, H. O.; Marchese, L.; Quím. Nova 2009, 32, 463.

Submitted: October 10, 2012

Published online: February 15, 2013 